\title{
Danger next door: new record of the whitefly Bemisia tabaci near to the Serra da Canastra National Park (southeast Brazil)
}

\author{
J. O. Oliveira ${ }^{a}$, L. R. P. Paschoal ${ }^{a, b}$ (D) and J. F. Nunes ${ }^{a, c *}$ (D) \\ ${ }^{a}$ Universidade do Estado de Minas Gerais - UEMG, Passos, MG, Brasil \\ ${ }^{b}$ Faculdade de Tecnologia Nilo de Stéfani - FATEC, Jaboticabal, SP, Brasil \\ 'Universidade do Estado de Minas Gerais - UEMG, Programa de Pós-graduação em Desenvolvimento Regional e Meio \\ Ambiente - PPGDRMA, Passos, MG, Brasil \\ *e-mail: juliano.nunes@uemg.br
}

Received: April 19, 2019 - Accepted: May 4, 2020 - Distributed: November 30, 2021

(With 2 figures)

\begin{abstract}
The whitefly Bemisia tabaci (Gennadius, 1889) is an important hemipteran (family Aleyrodidae) pest being considered one of the most invasive and devastating species of agricultural and horticultural crops. This species also damages flowering plants, through the direct feeding (i.e. phloem-sucking species) or due to the injection of toxins and transmission of viruses. Consequently, the whitefly promotes several ecological and economic problems worldwide (Leite et al., 2012, 2015; Ramos et al., 2018). This species has a wide distribution range in Brazil, occurring from Northeast (state of Pernambuco) to the South Region (state of Paraná) of the country. The infestation of B. tabaci (native from Asia) started in 1923, in the state of Bahia (Northeast Region), however, only by the end of 1960's the species reached the Southeast Region of Brazil (Fontes et al., 2012). At natural conditions (disregarding agricultural and horticultural crops) the whitefly is well documented and studied in northern Minas Gerais state in the Cerrado biome (Leite et al., 2012, 2015). The Cerrado is a tropical savanna ecoregion of Brazil, which is characterized by a high diversity and endemism of plants and animals. This biome occupies approximately $22 \%$ of the Brazilian territory, but only $8.21 \%$ of this area is legally protected. Fifteen national parks are located in this biome, the Serra da Canastra National Park (Figure 1) is considered one of the most important parks in Brazil, covering six municipalities in Minas Gerais state (1,978 $\mathrm{km}^{2}$ area) (ICMBio, 2019; Brasil, 2019). Until now, there were no documented records of $B$. tabaci nearly from or inside national parks in Brazil. In this note, we report a new record of the whitefly in the Southeast Brazil near to the Serra da Canastra National Park, also we discuss some ecological and conservation implications of this infestation.

From April to July 2019, entomological samples were performed monthly by the methods of sweeping net (active sampling) and Moerick trap (passive sampling) in areas with typical Cerrado stricto sensu vegetation, such as: Caryocar brasiliense Camb., Stryphnodendron adstringens Mart., Vellozia spp. and others Asteraceae, Caryocaraceae, Clusiaceae and Velloziaceae plants. The sampling site was situated at the "Trilha do Sol", an ecotourism attraction site, approximately $2 \mathrm{~km}$ distant from Serra da Canastra National Park in the municipality of Capitólio (Minas Gerais state)
\end{abstract}

(Figure 1). We detected some microhemipterans which were separated, analyzed and identified according to Bellows Junior et al. (1994), Malumphy (2004) and Oliva Molina (2017). Forty-two specimens (22 adults and 20 nymphs) were obtained and analyzed, and a subsample of fifteen adult specimens had their body length (BL) measured under a Leica ${ }^{\circledR}$ stereomicroscope (software Leica ${ }^{\circledR}$ IM50). These insects had prominent compound red eyes, dark yellow body (Figure 2A-C) (some individuals were covered with white powdery wax), hyaline wings (with no veins) with anterior margin straight (Figure 2A, B) and narrow appearance in rest position. The mean $( \pm \mathrm{SD}) \mathrm{BL}$ of the microhemipterans was $0.95 \pm 0.06 \mathrm{~mm}$ (smallest individual: 0.90 , largest individual: $1.06 \mathrm{~mm} \mathrm{BL}$ ). These characteristics fit well with the descriptions of Bemisia tabaci in Bellows Junior et al. (1994), Malumphy (2004) and Oliva Molina (2017). The identification was confirmed by Dr. Arlindo L. Boiça Junior of the Universidade Estadual Paulista (UNESP), Jaboticabal Campus, São Paulo state, Brazil. Voucher specimens collected were deposited in the entomological collection of the Plant health department of FCAV/UNESP - Jaboticabal Campus (São Paulo state, Brazil) under codes 2322, 2323 and 2324.

The new record presented herein is the first confirmed record of $B$. tabaci near to (maybe inside) a national park in Brazil. The Serra da Canastra National Park harbours a great variety of endemic plants, namely from families Asteraceae, Caryocaraceae, Clusiaceae and Velloziaceae (Nobrega and Nunes, 2012). This new pest record is worrisome in this national park, since $B$. tabaci is a vector of approximately 150 species of viruses (Fontes et al., 2012; Ramos et al., 2018), and it is known that whitefly infects Cerrado trees such as Caryocar brasiliense (Leite et al., 2012, 2015) - a common tree species near/within the park (Nobrega and Nunes, 2012). Also, we verified that the whitefly population is well-established in areas around the park showing constant and growing occurrence over months (Figure 2D). Byrne et al. (1996) showed that B. tabaci specimens could migrate $\sim 3 \mathrm{~km}$ (or even more) from their original area. Thus, we can conclude that B. tabaci may already be within the Serra da Canastra National Park. In this context, we suggest constant monitoring of this pest, and future studies are necessary to verify if this 


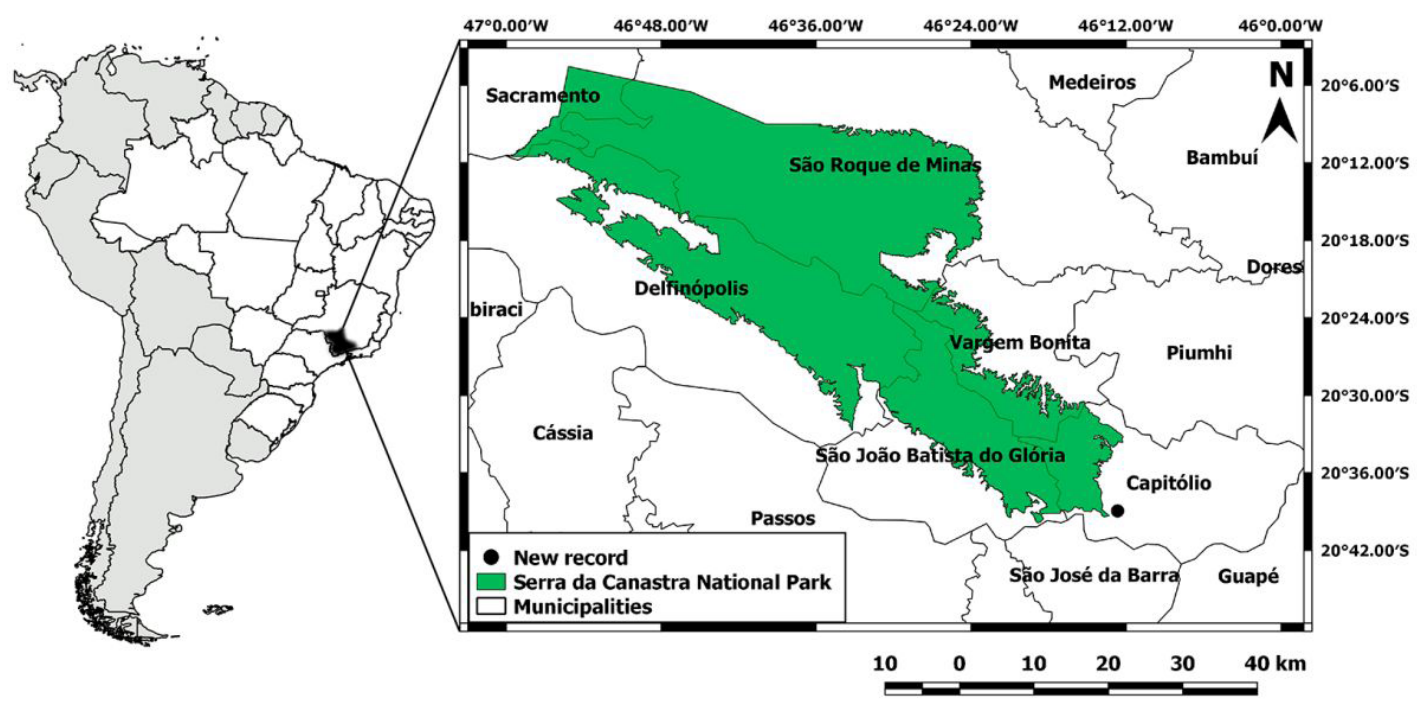

Figure 1. Map showing the new occurrence of Bemisia tabaci in the state of Minas Gerais (Southeast Brazil). This new record was registered near to the Serra da Canastra National Park.
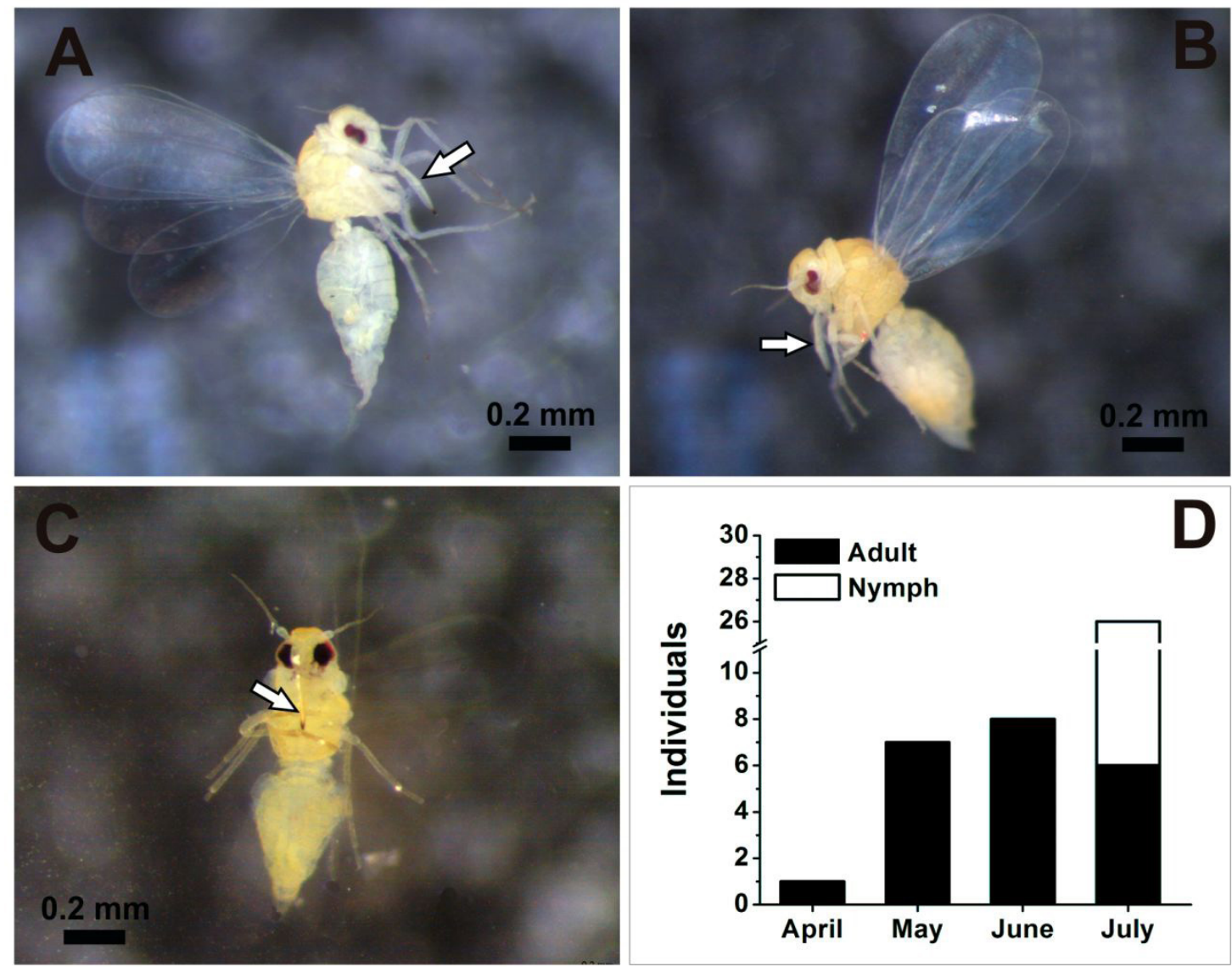

Figure 2. Bemisia tabaci (Gennadius, 1889). (A, B) Lateral view of the male and female microhemiptera, respectively; (C) Ventral view of the microhemiptera. White arrows show the stylet (fully extended) of the species. Note the black pigmentation of the stylet tip; (D) Total number of individuals collected during monthly samplings from April to July 2019 near to the Serra da Canastra National Park, Minas Gerais state, Southeast Brazil. 
microhemiptera can affect specific species of plants, using new hosts and if it can spread some kind of disease in the flora of this national park. Additionally, the means of introduction of the whitefly into the park is still unknown, but we suggest that $B$. tabaci was brought through some common culture in the southeastern region, such as tomatoes or coffee. The impact of whitefly presence on the flora of the Serra da Canastra National Park is still unknown and it may be enhanced due to human degradation - a serious problem that has been occurring in the study area in later years (Paschoal, pers. comm.). The danger is next door, now we must act!

\section{Acknowledgements}

We thank Dr. Arlindo L. Boiça Junior for confirming species identifications, Dr. Raphael C. Castilho for help with voucher specimens and Dr. Fernando J. Zara for the technical support provided during the determination of species. The first author thanks PAPq/UEMG Edital 01/2019 for granting a graduation scholarship. We especially thank the owners of Trilha do Sol for allowing the survey. We are extremely thankful to the anonymous reviewers that greatly improved the manuscript with relevant suggestions.

\section{References}

BELLOWS JUNIOR, T.S., PERRING, T.M., GILL, R.J. and HEADRICK, D.H., 1994. Description of a species of Bemisia (Homoptera: aleyrodidae). Annals of the Entomological Society of America, vol. 87, no. 2, pp. 195-206. http://dx.doi.org/10.1093/ aesa/87.2.195.

BRASIL. Ministério do Meio Ambiente - MMA, 2019 [viewed 11 August 2019]. O bioma Cerrado. Brasília. Available from: https://www.mma.gov.br/biomas/cerrado

BYRNE, D.N., RATHMAN, R.J., ORUM, T.V. and PALUMBO, J.C., 1996. Localized migration and dispersal by the sweet potato whitefly, Bemisia tabaci. Oecologia, vol. 105, no. 3, pp. 320-328. http://dx.doi.org/10.1007/BF00328734. PMid:28307104.

FONTES, F.V.H.M., COLOMBO, C.A. and LOURENÇÃO, A.L., 2012. Structure of genetic diversity of Bemisia tabaci (Genn.) (Hemiptera: Aleyrodidae) populations in Brazilian crops and locations. Scientia Agricola, vol. 69, no. 1, pp. 47-53. http:// dx.doi.org/10.1590/S0103-90162012000100007.

INSTITUTO CHICO MENDES DE CONSERVAÇÃO DA BIODIVERSIDADE - ICMBio, 2019 [viewed 11 August 2019]. Unidades de conservação - Cerrado: Parna da Serra da Canastra. Brasília. Available from: http://www.icmbio.gov.br

LEITE, G.L.D., VELOSO, R.V.D.S., ZANUNCIO, J.C., FERNANDES, G.W., ALMEIDA, C.I.M., FERREIRA, P.S.F., ALONSO, J. and SERRÃO, J.E., 2012. Seasonal abundance of hemipterans on Caryocar brasiliense (Malpighiales: Caryocaraceae) trees in the Cerrado. The Florida Entomologist, vol. 95, no. 4, pp. 862-873. http://dx.doi.org/10.1653/024.095.0407.

LEITE, G.L.D., VELOSO, R.V.D.S., ZANUNCIO, J.C., FERNANDES, G.W., ALMEIDA, C.I.M., FERREIRA, P.S.F., ALONSO, J. and SERRÃO, J.E., 2015. Cardinal distribution of sucking insects in Caryocar brasiliense (Caryocaraceae) in e Cerrado (Brazil). Revista Colombiana de Entomologia, vol. 41, no. 1, pp. 105-111.

MALUMPHY, C., 2004. Diagnostic protocols for regulated pests Bemisia tabaci. OEPP. Bulletin OEPP. EPPO Bulletin. European and Mediterranean Plant Protection Organisation, vol. 34, no. 2, pp. 281-288. http://dx.doi.org/10.1111/j.1365-2338.2004.00729.x.

NOBREGA, G.A. and NUNES, J.F., 2012. Identificação $e$ plaqueamento das espécies de árvores da Pousada Trilha do Sol. Capitólio. Technical consultancy.

OLIVA MOLINA, R.M., 2017. Eficacia de los agrotextiles como método de protección de cultivos. Almería: Universidad De Almería, 370 p. Tesis Doctorales en Ingeniería.

RAMOS, R.S., KUMAR, L., SHABANI, F. and PICANÇO, M.C., 2018. Mapping global risk levels of Bemisia tabaci in areas of suitability for open field tomato cultivation under current and future climates. PLoS One, vol. 13, no. 6, pp. e0198925. http:// dx.doi.org/10.1371/journal.pone.0198925. PMid:29902221. 